\title{
An Overview of Franchising Law: Why is it Important?
}

\author{
Imed Eddine Bekhouche ${ }^{1} \&$ Soheyb Salah Kahlessenane ${ }^{2}$
}

\author{
${ }^{1}$ School of Law, UUM College of Law, Governance, and International Studies (COLGIS), Universiti Utara Malaysia, \\ 06010 Sintok, Kedah, Malaysia \\ ${ }^{2}$ School of Business Management (SBM), College of Business (COB), Universiti Utara Malaysia, 06010 Sintok, Kedah, \\ Malaysia
}

Correspondence: Imed Eddine Bekhouche, E-mail: imed.bekhouche@gmail.com

Received: April 8, 2018 Accepted: June 4, 2018 Online Published: June 11, 2018

doi:10.11114/ijlpa.v1i1.3355

URL: http://dx.doi.org/10.11114/ijlpa.v1i1.3355

\begin{abstract}
The main objective of this paper is to highlight the importance of specific franchising law, for that the armchair library approach employed. The obtained results have shown that there is no doubt of the role of franchising regulations to enhance the development of franchising around the globe.
\end{abstract}

Keywords: Franchising, Law, Global, Important

\section{Introduction}

Franchises are a part of our daily life. We have almost all gotten a cup of coffee in the Dunkin' Donuts in the morning, booked a room at the Marriott hotel for our holidays, or had a quick dinner at McDonald's. They are important for our daily life; however, looking at the big picture, franchises have an even greater impact than we might recognize. This form of business development has been used for over one hundred years ago. The popularity of franchising in the last decades has grown enormously due to the intense processes of globalization. Because of the intensive processes of globalization, cultures mix, consumption habits change, people tend to travel more and look for the same famous brands of the same goods, services and quality (Kavaliauske \& Vaiginiené, 2011). The word "franchise" comes from the French word "Fraunchise", which derives from the French word "frank" - a free person, free to do something. The English word "franchising" was originally used to describe the exemption from any prohibition, authorization or privilege for which a company is allowed to do or not to do something for which it would generally not have rights (Alon, Alpeza, \& Erceg, 2007). From a legal point of view, a franchise is a binding contract between two partners, in which the franchisor grants franchisees the right to implement their business system in exchange for the payment of fees and royalties (Kerkovic, 2010). Simply, A franchise occurs when someone develops a business model and then sells the rights to conduct business with this model to another entrepreneur, the franchisee. The businessman who sells the rights is the franchisor.

\section{Background of the Study}

Franchising is a model of business growth, which significantly reduces uncertainty in the riskiest growth phases: the start of the company and the phase of rapid growth. Due to the advantages recognized in the application of the franchise business model for both start-ups (using knowledge of the franchisor, experience and brand) and for successful companies with growth potential (growth using financial resources and knowledge of the local business market), the franchise has been successfully applied in developed countries for decades (Alpeza, Perić, \& Šoltić, 2012).

Furthermore, franchising has become an important strategy for business growth, job creation and economic development, and has also become an effective way for companies to enter foreign markets or expand internationally (Hoffman, Munemo, \& Watson, 2016). The franchises have a great impact on the world economy, based on FranData in 2015 research franchising accumulates a turnover of 1.6 billion US dollars, representing $2.3 \%$ of world GDP, has 2.2 million of companies involved and employs nineteen million people. and franchise economic products represent a significant portion of the national GDP on average by 4\% (Alon et al., 2007).

In general, countries fall into one of four groups. The first group consists of countries that have laws that directly 
regulate franchising; This group includes about 33 countries. The second group consists of countries that have laws that directly or indirectly influence the franchise, but do not have laws that directly regulate the franchise. The third group includes countries that do not have national franchise legislation, but the individual states and provinces of the country have specific laws for franchises; a good example is Canada. In the fourth group there are countries in which both federal and state governments regulate franchising in varying degrees; A good example is the United States (USA) (Ofodile, 2014). Whether the absence of the legal regulation of franchising represents an obstacle for its development and expansion?

\subsection{Literature Overview}

Researches carried out in Croatia by Alon et al. (2007) and Alpeza, Erceg, and Oberman Peterka (2015) show the perception of lawyers about the threats and opportunities of franchises development in Croatia; two main obstacles that are directly related to legal regulation were identified: an inconsistent legal system and inadequate protection of the intellectual property rights of the franchisor. During the research it was confirmed that the franchise is still in the early stages of development in Croatia, and the most serious problems for the further development of franchising in Croatia are the lack of franchise legal regulations and insufficient knowledge of the franchise as a business model (Erceg, 2016). In New Zealand, to promote a successful franchise home-grown, it is logical that all franchises to be on as even a playing field as possible. There must be a set of fair rules that govern franchising business format, and a law developed and implemented will contribute to better protection of both the franchisors and the franchisees than the status quo. The costs associated with regulation will be compensated by the benefits (Gunasekara \& Sims, 2007). Policy makers in emerging markets have observed the economic contribution of franchises in developed markets and are increasingly looking for ways to develop and regulate this form of business. According to the sources of the International Franchise Association, in 1993 at least twenty-four countries have developed a trade association specialized in franchising and in ten years later there are at least fifty-five national and regional franchising associations worldwide. The attractiveness of emerging markets in the franchise sector and the efforts of host markets to stimulate economic development through franchising have led to the rapid expansion of franchises worldwide (Alon, 2006). According to Andrew Terry to date only about thirty countries have adopted a special law on franchising. Most countries rely simply on basic of commercial laws to regulate franchising, and the question of whether specific franchise regulations are necessary for the healthy development of franchising remains controversial (Binh, 2012).

\section{Method}

Social research is a systematic study into social, political or other fact-conditions, to discover unknown or party known factors working behind particular phenomenon, to understand why something happens and to draw inferences and general conclusions, it is to identify the cause and effect of certain problem (Yaqin, 2007). This paper is an attempt to find out the importance of franchise specific law in developing and expansion of franchising. In conduction this paper, it is intended to use the exploratory study on franchising globally to know the value of franchising law. The armchair library approach employed for the collection of the primary legal materials. For this purpose, the Library of Universiti Utara Malaysia-UUM, the Faculty of Law Library used to source the primary legal material. The secondary data, books, articles, reports and online database equally sourced through the library approach.

\section{Results}

\subsection{The Importance of Franchising}

The franchise has become a significant form of business ownership in many countries. In the United States, where it is believed that they were pioneers, there are 909,253 franchise companies with 21 million jobs and 2.31 billion dollars of annual output. These remarkable trends are gradually observed in many countries around the globe (Olufunmilola, Anna, \& David, 2015). The Chief Economist of the United States Department of Commerce, International Trade Administration, Dwivey in 2002 wrote that: "franchising brings about the transferring of technology and business methods, the development of SMEs, the creation of jobs, and the offering of quality goods at a reasonable price" (Alon, 2006). However, the influence of the franchise is broader, both for the national economy of the countries involved, and for the operators involved in this form of business.

\subsubsection{Job Creation}

The most obvious advantage of franchising for the national economy is the creation of new jobs not only directly in the franchising sector, but also indirectly in related industries. Thus, for example, if a food franchise network is established, there will be a demand for products and services that are used in the franchise or in relation to it (Unidroit.org, 2016). Moreover, franchising systems "contribute to economic development through stimulated purchases, that is, by offering jobs and income to their employees, franchisors stimulate local demand for various goods and services (Alon, 2006). For example, in Australia (the population of 20 million people) there are about 850 franchising, which make up 
approximately 54,000 outlets throughout the country, with 507,000 people employing in this field (Peretiatko, Humeniuk, Humeniuk, D'Souza, \& Gilmore, 2009). The Franchise Business Economic Outlook 2015 report, published in January 2016, indicates that the franchising will outperform the US economy for the sixth consecutive year in terms of overall growth. The report predicts that in 2016 the economic production of the US franchise sector will increase by $3.1 \%$ to $\$ 944$ billion, and the direct employment of franchises will grow by 278 thousand jobs. The January 2016 report highlights the following: Over the past five years, the average annual employment growth in the franchising sector has been $2.6 \%$, or nearly $2 \%$ more than all business in the entire economy. Over the past five years, the franchise industry has added nearly 1 million jobs to the economy (US ITA, 2016). In France, there are 1,658 franchisors and 65,059 franchised stores, which employ 323,497 people and produce more than 50,680 million euros in turnover (Ferreira, 2016). A study conducted by African franchisors showed that, on average each franchisor created about 32 direct jobs per year (Alon, 2006). In Canada, according to data collected by the EFF, in 2006, 9.65 million people were employed in the franchising sector, 9 million by franchised outlets around the country. The data collected by the EFF show that in Mexico in 2006, 50,000 people were employed in the franchising sector. In Egypt, employment in the franchising sector is estimated at 45,012 , with a growth rate which about $24 \%$ over the past two years (Unidroit.org, 2016). China with 3.5 million employees, Japan with 2.4 million employees and a turnover of 243 billion euros, South Korea with 1.2 million employees and a turnover of 95 billion euros in 2009. Other fast-growing franchise markets are Brazil with 0.72 employees, also the franchise is rapidly developing in Turkey and Poland, which in 2009 employed 0.25 and 0.35 million employees in the franchise business, respectively (Kavaliauskè \& Vaiginienè, 2011). In the United Kingdom, the statistics of British Franchise Association shows that the annual turnover of a franchising in 2015 was 15.1 billion pounds sterling, while more than 621,000 jobs were attributed to the franchise, and there was an increase of $14 \%$ of active business format franchising systems were existing, with a total of 44,200 franchisee-own business (Thebfa.org, 2015). Kazakhstan has over 350 franchises, has opened more than 3000 franchise companies, which employ more than 17,000 people, and the turnover of the franchising sector reaches one billion dollars a year (Sayabaev et al., 2016). The annual growth of employees justifies the image of franchises as a job generator in middle-sized companies that guarantee stability and security even in difficult times. According to a survey by Deutsche Bank Research, sales of German franchise systems are expected to increase 7\% per annum to 70 billion Euros, which certainly positively affects employment (Kußmaul, Waschbusch, Knoll, Ruiner, \& Staub, 2012).

\subsubsection{Tax Revenue Raising}

Tax increases help emerging markets develop their general and institutional infrastructures. International franchisors increase the tax base directly through their participation and indirectly through their franchisees and the small business network. The tax multipliers are proportional to the multipliers of production and employment. Multinational franchisors are more likely to pay taxes as a model for corporate citizens than local companies that are either connected, elusive or unprofitable. For example, Kodak paid more taxes during the first six months of operations in China than Fuda Co., one of its purchased companies, has paid for 14 years. In one of the cities where the company is located, Xiamen is the largest contributor by paying taxes (Alon, 2006).

\subsection{The Importance of Franchise Law}

Franchising is used by emerging markets as a tool for economic development and global integration (Alon, 2006). But since franchising in emerging markets is a new phenomenon, few papers have examined that specific franchise-specific law can help to ensure the continued growth of the franchise or explore the reasons for enacting a specific law in franchising.

The franchise is an important driver in the economy of the United States. franchising is responsible for one in seven jobs in the country and accounts for 50\% of all retail sales in the United States through 75 sectors. In the United States, there are more than 780,000 franchise companies that employ more than 8.8 million people and make up over 890 billion dollars in direct economic output (US ITA, 2016). Moreover, according to the Franchising Association of South Africa (2012), the franchising sector accounts for about $11.8 \%$ of South Africa's GDP. The number of franchise systems increased from 156 in 1994 to 551 in 2010. In 2010, these franchise systems exist in a total of 30,000 stores, most of which are franchised as small and medium-sized independent enterprises (SMEs), and They employed 478,000 people (Sigué, 2012).

Given the positive role that a franchise can play in the world economy, it is important that legal practitioners have an adequate understanding of how it is regulated throughout the world. An inexorable march to regulate franchises continues as countries such as Argentina, which previously did not specifically regulate the franchise, have adopted specific franchise laws over the past 12 months (Abell, 2016). On 2006, the Franchising Centre of the Osijek Centre for Entrepreneurship conducted a survey of 50 people, asking what examinees (representatives of banks, businessmen and lawyers) thought of the barriers facing franchising in Croatia. their responses included the lack of legal regulation of 
franchising as the first obstacles to the development of franchising in Croatia (Alon et al., 2007). Furthermore, one of the most important obstacles faced by San Francisco Coffee House during the development of its franchise network in Croatia is: there is no legal regulation of the franchise. At the moment there are no standards for franchising contracts, and there are not enough lawyers who are familiar with the franchise (Alon et al., 2007). In Jordan, one of the main problems is the absence of a specific legal framework for the regulation of franchising, where the rights and obligations of the parties to the franchise and remedies available remain ambiguous. in addition, the lack of specific legislation would undoubtedly discourage or at least slow down the progress of foreign and local investors in the creation of franchises in Jordan, as they could not reasonably predict what awaits them on the market (Khasawneh, Yaacob, \& Rahman, 2016).

According to Professor Andrew, franchising requires a fundamental law to support its orderly development. In Thailand there is no uniform legislation and regulations, though there is support for the franchising sector through political and other laws. This leads to a possible concern about the significant expansion of the franchising sector in Thailand. Although there is no unified law, the franchising sector in Thailand is growing. The problem at this stage is that in the growing sector there is lacks the necessary specific legal mechanism to regulate it (Wisuttisak \& Binh, 2016). Moreover, it has been observed that a specific franchising law on deductibles is required, as the law helps to solve problems related to the proper balance between the parties in the franchise agreement and to ensure that no abuses occur in the agreement or that when occur they did not repeat again (Wisuttisak \& Binh, 2016). The rapid growth of franchising in China has not been without problems; those problems were summarized by Guo (2004) the Chairperson of the CCFA, in his speech to the CCFA International Franchise Forum in 2004:

- Franchisors can start the franchise without fulfilling the basic requirements, such as the presence of a registered trademark or sufficient experience or a proven system.

- Franchisors may not disclose information adequately or sufficiently-information about the risk of the operation may not be disclosed adequately or the potential gain may be exaggerated.

- Franchisors may stop providing permanent support and services after the franchise fees have been collected or involved in other fraudulent practices.

- The parties of franchising (franchisor and franchisee) may knowingly breach the franchise contract.

- Franchisees may not pay franchising fees for franchisors as indicated or may violate the intellectual property of the franchisors (Guo, 2004).

The introduction of the Franchise Regulation in 2007 is the official response to these problems. In China, as in other countries, the law plays an important role in improving the environment for franchising (Wang, Zhu, \& Terry, 2008). For example, in 2002, Kazakhstan passed a franchise law which entitled "On Complex Entrepreneurial Licenses ". The law is the first separate part of the Kazakh legislation on franchising, contain definition of franchise contracts and the creation of a state support fund for franchises in Kazakhstan (Parshina, 2009).

In addition, most foreign franchisors chose not to use the franchise as a means of penetrating the Ukrainian market. One reason was the relatively low purchasing power of Ukrainians, a poor legal framework to support franchise agreements was an important factor that hampered the use of the franchise. This was recently reviewed with the introduction in early 2004 of both the civil code and the commercial code, in which franchising agreements were specifically addressed and given extensive legal recognition (Peretiatko et al., 2009). Moreover, in Australia, after a period in which an attempt was made to avoid mandatory legislation, by choosing a franchising self-regulation through voluntary application of the Franchise Code of Practice applicable to the franchisors (including sub-franchisors), franchisees, service providers, consultants and state small business corporations, the position of the franchise was reviewed by the House of Representatives Standing Committee on Industry, Science and Technology in the study of business conducting. In its report, the Committee concluded that self-regulation did not work and that it was necessary to underpin codes of conduct with legislation. This request has led the Australian government to adopt a mandatory code of conduct for franchises (Unidroit.org, 2016). The Australian Franchise Council, in a subsequent submission to the Government on the revision of the Franchise Code of Conduct, noted that: our members believe that the Code has had a beneficial effect on the franchising sector. There is a huge consensus about the availability of code and the franchise sector is not trying to revise the code from a political point of view (Binh, 2012).

Moreover, self-regulation of franchises in the EU has no uniformity and not clear, consistent, and effective approach to enforce the rules, and there is a significant conflict of interests between the interests of franchisors and franchisees. The result of this dysfunctional regulation is that franchising in the EU is substantially underperforming. This is shown by the fact that $83.5 \%$ of the franchise turnover in the EU is concentrated in only $25 \%$ of the Member States and represents only $1.86 \%$ of EU GDP, compared to $5.95 \%$ of GDP in United States and 10.83\% of GDP in Australia (Abell \& Bird, 
2016).

However, the introduction in 2005 of the law on franchising in Vietnam became, in fact, a turning point in the development of the franchise in this country. In just 5 years since the introduction of the law of franchising, the number of franchising systems has increased to 96, as both foreign and domestic companies have embraced franchising. Prior to the enactment of the 2005 commercial law, the franchise was considered a technology activity and was governed by licensing laws and technology transfer laws. These regulations created a series of problems for the franchise. Due to these legal obstacles, it is easy to understand why, despite the fact that in 1997 he joined Vietnam, KFC - the largest foreign franchisor in Vietnam by the number of systems - did not use the franchise to expand its system at the beginning. Vietnam is one of the 33 countries that have adopted a specific franchise regulation to stimulate the development of franchises and solve emerging problems in the franchise sector (Binh \& Terry, 2011). Subsequently, the late development of the franchise in Vietnam was the result of the late development of the economic and legal system necessary to support it (Binh, 2012). Moreover, Malaysia before the enactment of the 1998 Franchise act on October 1998, the franchise was governed by contractual principles, and the absence of complex provisions or regulatory guidelines allowed the parties to freely discuss the terms of their franchise agreement. On the contrary, the Franchise Law regulates the franchise sector, since it not only controls the terms of any franchise agreement, but also implements a system of registration of franchisors, franchisees and franchise brokers. Although it has created a regimented legal structure for the franchising industry in Malaysia, the franchise law provides certainty and great protection for Malaysian businesses, especially for small and medium businesses (Malaysian Franchise Association, 2018).

In Nigeria where there is no specific law of franchise, Ofodile view that: "Nigeria can learn a lot from emerging markets like China, Mexico, Brazil, India and South Africa as far as creating the legal and regulatory environment for franchising is concerned. In today's highly competitive global market, countries are taking steps to create business environment that is conducive for innovation and entrepreneurship. To attract international franchisors, countries such as India, China, and Brazil are taking steps to make franchising regulation more transparent and to improve market governance more generally. Examining the regulatory environment for franchising in some emerging market can offer valuable insights to policymakers and stakeholders in Nigeria" (Ofodile, 2014)

The most obvious reason for the regulation of franchise agreements were the practical problems that arose in the context of franchising activities. In most cases, these problems stressed the abuse committed by the franchisor under the circumstances of a large discrepancy in the contractual balance of the parties in the franchise agreements. The parties often have a very different bargaining capacity: the franchisor is often a large and complex business organization with significant franchise experience and controls the terms of the franchise agreement, while the franchisee may have little experience in doing business and in each case, often must "take or leave" a franchise agreement as it is offered (Kerkovic, 2010).

Moreover, the objectives of the specific legislation on franchises can be divided into two main categories of goals economic efficiency objectives and social welfare objectives. Economic objectives include promoting fair competition or business development (for example, China and Korea), reducing court costs, reducing risk, promoting economic growth and increasing certainty (for example, in Mexico and Australia). A common theme among purposes of regulation is the idea of promoting the development and/or maintaining the economic health of the franchise sector, as outlined, for example, in the purposes of legislation in Kazakhstan and Australia.

Social welfare objectives can also contribute to increasing economic efficiency, as they protect the interests of the participants, in particular the franchisees. Social welfare objectives include the non-discrimination of franchisees, the protection of rights, the improvement of standards of conduct and the promotion of the interests of franchisees. Some laws set these goals as a whole in terms of the protection of both franchisors and franchisees, as in South Korea; The People's Republic of China and in Australia - "protecting the participants". The regulatory framework of the country, as well as government actions or inaction can facilitate or prevent the development of a franchise in any country (Hoffman et al., 2016).

\section{Conclusion and Recommendations}

Forty-six years ago, California introduced the first legal regime for franchising. Today, more than 30 countries have introduced specific franchise laws of greater or lesser sophistication to solve problems related to information and imbalance of power in franchisor-franchisee relationship. The franchising specific law help to ensure that franchisees are provided with proper information to assist them to make a well-informed investment decision, substantive rules guide franchising parties to better conclude and perform the franchise agreements. The franchising specific law guarantee the authenticity and transparency of franchising documents produced by franchisors and the credibility of other persons involved in the franchising process. However, despite the importance of franchising in the economic development there is a lack of concern in this system of business especially in emerging market. A systemic review 
performed on 126 studies of franchising done by Nijmeijer, Fabbricotti, and Huijsman (2014), the results show that, only seven studies being conducted in Asia, while, these studies were drawn in North America, United Kingdom, and Europe. For thus the scholars are invited to investigate the franchising in other part of the globe such as Africa and Asia especially in the legislation and policies aspects (Nijmeijer et al., 2014).

\section{References}

Abell, M. (2016). The Franchise Law Review - Gómez-Acebo \& Pombo. Te Franchise Law Review - Edition 3.

Abell, M., \& Bird, B. (2016). Legal Perspective of The Regulatory Framework and Challenges for Franchising in the EU. European Parliament's Committee on the Internal Market and Consumer Protection., IP/A/IMCO/2016-08 PE 587.317(Sep 2016).

Alon, I. (2006). What are the Social and Economic Benefits and Costs of Global Franchising? Service Franchising (pp. 27-57): Springer.

Alon, I., Alpeza, M., \& Erceg, A. (2007). Opportunities and threats regarding the development of the franchising business model in Croatia. Paper presented at the Seventh International Conference on "Enterprise in Transition.

Alpeza, M., Erceg, A., \& Oberman Peterka, S. (2015). Overview Development of Franchising In Croatia Obstacles And Policy Recommendations. Review of Innovation and Competitiveness: A Journal of Economic and Social Research, 1(1), 5-24.

Alpeza, M., Perić, J., \& Šoltić, A. (2012). The role of creativity and innovation in implementation of franchising business model in Croatia. Paper presented at the 32nd International Conference on Entrepreneurship and Innovation Podim-Potentials of Creative Industries.

Binh, N. B. (2012). The Role and Influence of Vietnam's Franchise Law on the Development of Franchising: a Multiple Case Study: University of New South Wales.

Binh, N. B., \& Terry, A. (2011). Good morning, Vietnam! Opportunities and challenges in a developing franchise sector. Journal of Marketing Channels, 18(2), 147-163.

Ferreira, M. A. M. (2016). Interfirm Networks Franchising, Cooperatives and Strategic Alliances A Book Review. International Journal of Latest Trends in Finance and Economic Sciences, 6(2), 1146-1147.

Gunasekara, G., \& Sims, A. (2007). Franchising: A case for regulation. University of Auckland Business Review, 9(1).

Guo, G. (2004). Establishment of standardised market rules for the rapidly growing franchise sector. A speech given by Geping Guo at the CCFA 2004 Intemational Franchising Forum in Shanghai,(China on October 19. 2004.).

Hoffman, R. C., Munemo, J., \& Watson, S. (2016). International franchise expansion: the role of institutions and transaction costs. Journal of International Management, 22(2), 101-114.

Kavaliauskè, M., \& Vaiginienè, E. (2011). Franchise business development model: Theoretical considerations. Business: Theory and Practice, 12, 323.

Kerkovic, T. M. (2010). The Main Directions in Comparative Franchising Regulation-Unidroit Initiative and its Influence. European Research Studies, 13(1), 103.

Khasawneh, M. S., Yaacob, N., \& Rahman, R. A. (2016). Current Laws Governing Franchise Agreement in Jordan. Asian Social Science, 12(4), 45.

Kußmaul, H., Waschbusch, G., Knoll, J., Ruiner, C., \& Staub, N. (2012). Franchising-a key to success in times of financial and economic crises?! International Journal of Entrepreneurial Venturing, 4(3), 309-326.

Nijmeijer, K. J., Fabbricotti, I. N., \& Huijsman, R. (2014). Making franchising work: A framework based on a systematic review. International Journal of Management Reviews, 16(1), 62-83.

Ofodile, U., Ewelukwa,. (2014). Franchising Law in Nigeria-Part II- Franchising Law: Does Nigeria Need One? Do other countries have them? Advinsing Entrepreneurship though Franchising, May(1-6).

Olufunmilola, D., Anna, W., \& David, K. (2015). Entrepreneurial tendencies in franchising: evidence from the UK. 
Journal of Small Business and Enterprise Development, 22(1), 82-98.

Parshina, O. (2009). Franchising in Kazakhstan.

Peretiatko, R., Humeniuk, A., Humeniuk, M., D'Souza, C., \& Gilmore, A. (2009). Franchising in Ukraine. European Journal of Marketing, 43(1/2), 21-30.

Sayabaev, K., Nurgaliyeva, Z., Temirova, A., Kasenova, A., Dzhamburbaeva, M., Zhangirova, R., ... Shamuratova, N. (2016). Finance, Franchise and Their Impact on Tourism. Journal of Internet Banking and Commerce, $21(3), 1$.

Sigué, S. P. (2012). The promises of franchising in Africa: the need for a critical examination: Taylor \& Francis.

Thebfa.org. (2015). Franchise Industry Research . The British Franchise Association. (Retreived from https://www.thebfa.org/external-relations-pr/franchise-industry-research/ [Accessed 1 Apr. 2018].).

Unidroit.org. (2016). The UNIDROIT General Assembly celebrates the Institute's 90th Anniversary with a Special High-Level Session. (Retreived from: https://www.unidroit.org/index.php?option=com_content\&view=article\&id=1999 [Accessed 9 Jan. 2018].).

US ITA. (2016). Top Markets Report Smart Grid: Country Case Study - United Kingdom. 1-3.

Wang, Z. J., Zhu, M., \& Terry, A. (2008). The development of franchising in China. Journal of Marketing Channels, 15(2-3), 167-184.

Wisuttisak, P., \& Binh, N. B. (2016). The Regulatory and Commercial Environment for Franchising in Thailand in the Wake of the ASEAN Integrating Market. IIUM Law Journal, 24(1), 107.

Yaqin, A. (2007). Legal Research and Writing. Malaysia: Lexis Nexis, 2007.

\section{Copyrights}

Copyright for this article is retained by the author(s), with first publication rights granted to the journal.

This is an open-access article distributed under the terms and conditions of the Creative Commons Attribution License which permits unrestricted use, distribution, and reproduction in any medium, provided the original work is properly cited. 